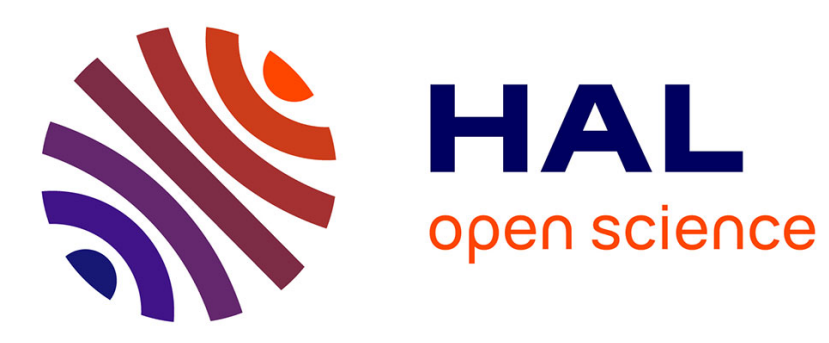

\title{
Polyoxazoline associated with cardanol for bio-based linear alkyl benzene surfactants
}

\author{
Benoit Delage, Benoit Briou, Thomas Brossier, Sylvain Catrouillet, \\ Jean-Jacques J Robin, Vincent Lapinte
}

\section{- To cite this version:}

Benoit Delage, Benoit Briou, Thomas Brossier, Sylvain Catrouillet, Jean-Jacques J Robin, et al.. Polyoxazoline associated with cardanol for bio-based linear alkyl benzene surfactants. Polymer international, 2019, 68 (4), pp.755-763. 10.1002/pi.5763 . hal-02067105

\section{HAL Id: hal-02067105 https://hal.science/hal-02067105}

Submitted on 14 Mar 2019

HAL is a multi-disciplinary open access archive for the deposit and dissemination of scientific research documents, whether they are published or not. The documents may come from teaching and research institutions in France or abroad, or from public or private research centers.
L'archive ouverte pluridisciplinaire HAL, est destinée au dépôt et à la diffusion de documents scientifiques de niveau recherche, publiés ou non, émanant des établissements d'enseignement et de recherche français ou étrangers, des laboratoires publics ou privés. 


\title{
Polyoxazoline Associated To Cardanol For Bio-Based LAB Surfactants
}

\author{
B. Delage, B. Briou, T. Brossier, S. Catrouillet, J.J. Robin, V. Lapinte*
}

ICGM, Univ Montpellier, CNRS, ENSCM, Montpellier, France

e mail: vincent.lapinte@umontpellier.fr

\begin{abstract}
Well-defined linear alkyl benzene (LAB) surfactants $\left(\mathrm{COx}_{n}\right)$ were successfully synthesized using cardanol as green phenolic alternative and initiator for polyoxazoline (POx) hydrophilic block of the nonionic surfactants. Various HLB values were investigated in varying the POx length according to [monomer]/[initiator] ratio. The chemical structure of the surfactants in particular the terminal groups were well-identified by Maldi-Tof spectroscopy demonstrating the good progress of the cationic ring-opening polymerization (CROP). The $\mathrm{COx}_{n}$ surfactants spontaneously self-assembled in water at a critical aggregation concentration $(\mathrm{CAC})$ of $1-2 \mu \mathrm{mol} / \mathrm{L}$ into nano-objects characterized by a hydrodynamic diameter of 11-24 nm and a number of aggregation ranging from 30 to 60 according to wormlike micelle model.
\end{abstract}

KEYWORDS: Cardanol, surfactant, LAB, polyoxazoline, cationic polymerization. 


\section{Introduction}

Surfactants are largely used in applications such as detergency, paint formulations, phytosanitary products, wastewater treatment, metal extraction processes and so on. The demand in various chemical structures adapted to these specific uses remains high and the research is nowadays oriented towards the use of renewable raw materials such as lipids, polysaccharides, proteins... Some natural molecules such as acylsugars, glycolipids, sophorolipids exhibit surfactive properties $[1,2]$ but their extraction at industrial scale is economically not sustainable.

Cashew nut shell liquid (CNSL) is an agricultural by-product produced in significant tonnages in various areas of the world making it an attractive substitute in a broad range of applications. The chemical and thermal treatments by acids and distillation under reduced pressure lead to the decarboxylation of anacardic acid giving cardol, 2-methylcardol and cardanol [3]. This last compound has been largely studied and functionalized following various routes to give polymers and additives as reviewed by Caillol and Wadgaonkar [4],[5]. Concerning the surfactants, various modifications of cardanol have been reported. Epoxidized cardanol was modified by benzoxazine ring and polyether chains to give surfactants for the stabilization of epoxy emulsions [6]. The direct sulfonation of the aromatic ring has also been described by Peungjitton et al. giving surface tension close to that of dodecylbenzene sulfonate [7]. Sulfonated cardanol-formaldehyde resins found applications in the area of coal water slurry as dispersants with a good surface activity [8]. The indirect sulfonation of cardanol and hydrogenated cardanol where the sulfonate group is linked to the aromatic ring has been widely explored using for instance sulfones [9-12]. Phosphorylated cardanol has been synthesized by direct phosphorylation of cardol for the coating of nanoparticles in the area of ferrofluid production [13]. According to an easy synthetic route, surfactants based on carboxylated cardanol have been applied to the stabilization of microemulsions [14]. The 
synthesis of cardanol amine has been reported by Caillol et al. to lead to ionic and zwitterionic surfactants and epoxy hardeners $[15,16]$. Otherwise, the synthesis of tertiary, secondary and primary amines have been reported [17] and applied in the area of the organomodification of clays where they revealed a good efficiency in exfoliation and for the compatibilization with thermoset resins $[18,19]$. At last, some peculiar architectures based on cardanol such as gemini and betaïne surfactants should be reported [20-24].

Nowadays, a crucial challenge is the replacement of toxic surfactants such as nonyl phenol ethoxylate (NPE) surfactants extensively employed in cleaning chemical formulations as wetting agents, dispersants or emulsifiers. The toxicity of NPE mainly affects the aquatic environment with risks of bioaccumulation. Substitution of NPE by cardanol ethoxylate (CE) has already been described and shows a better biodegradability even if the toxicity coming from the short PEO chains remains problematic [25, 26] [27] (Figure 1). Consequently, this work focuses on the functionalization of the cardanol moiety by hydrophilic chains which would be neither PEO nor glycolipids as they have already been described [5, 25, 26] [27].

Polyoxazolines (POx)s substituted by methyl and ethyl groups, are promising water soluble polymers especially on account of their low toxicity. This class of polymers has been developed 50 years ago [28] and renewed interest this last decade as it has been reviewed by Hoogenboom [29, 30] and the special issue in European Polymer Journal (2017, Vol. 88). They find applications in various areas such as hydrogels, surface modifications, health field, surfactants [31-36]. Their use as surfactant has been reported for the first time by Kobayashi by designing copolymers containing both hydrophilic and lipophilic POx blocks [37]. More recently, POx blocks have been linked to bio-based blocks such as glycopolymers, fatty derivatives or to petro-based blocks including polysiloxanes, aliphatic polyesters, fluorinated chains... giving various amphiphilic copolymers with surfactant or self-assembling properties 
[38-54]. Their use as surfactant for instance for emulsion polymerization or solubilization of dyes have recently been reported $[55,56]$.

Herein, the association of the peculiar phenolic lipid, cardanol, with an hydrophilic poly(2methyl-2-oxazoline) chain was explored. The synthesis of cardanol oxazolinate $\left(\mathrm{COx}_{n}\right)$ surfactants using cardanol as macroinitiator for cationic ring-opening polymerization (CROP) of 2-methyl-2-oxazoline (MOx) is described aiming at producing a bio-sourced linear alkyl benzene $(\mathrm{LAB})$ alternative surfactants.<smiles>[R]c1ccc(OCCC(C)(C)C)cc1</smiles>

Nonylphenol ethoxylate (NPE)<smiles>[R]c1cccc(OCCC(C)(C)C)c1</smiles>

Cardanol ethoxylate (CE)<smiles>[R]c1cccc(OC(=O)C(C)N(CCC(C)(C)C)C(C)=O)c1</smiles>

Cardanol oxazolinate $\left(\mathrm{CO}_{n}\right)$

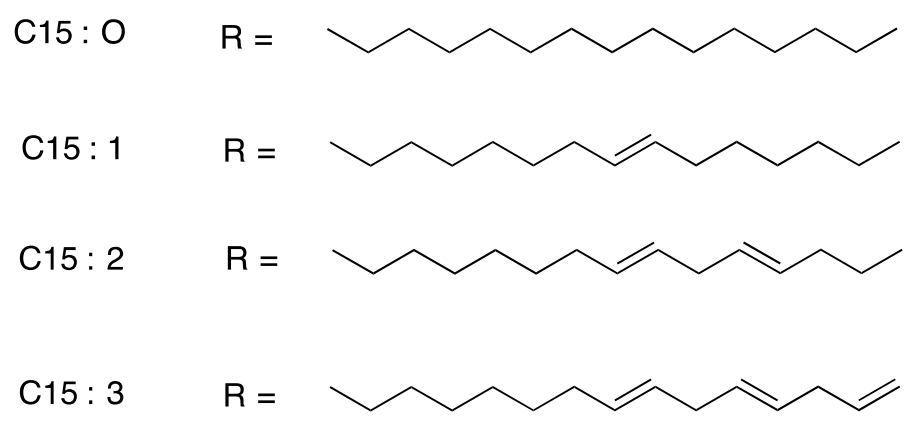

Example<smiles>C=CC/C=C/C/C=C/CCCCCCCc1cccc(OC(=O)CN(C)C(C)=O)c1</smiles>

Figure 1. Chemical structure of $\mathrm{COx}_{\mathrm{n}}$ and nonyl phenol derivatives 


\section{Experimental section}

\section{Materials}

2-Methyl-2-oxazoline (MOx) from Sigma Aldrich and acetonitrile (ACN) from Carlo Erba were purified by distillation under $\mathrm{CaH}_{2}$ before use and stored under dry nitrogen. Cardanol from Cardolite was used without purification. Chloro acetylchloride, 1-iodododecane, 1iodooctadecane, piperidine, triethylamine, sodium iodide and anhydrous dichloromethane were used as received.

\section{Analytical Techniques}

Nuclear magnetic resonance (NMR) spectra were conducted on a NMR Bruker Avance I 300 $\mathrm{MHz}$ in $\mathrm{CDCl}_{3}$. The chemical shifts were in part per million (ppm), where (s) means singlet, (d) doublet, (t) triplet, (m) multiplet and (dd) doublet of doublet. For $\left({ }^{1} \mathrm{H}\right.$ NMR) chemical shifts were referenced to the peak of residual $\mathrm{CDCl}_{3}$ at $7.26 \mathrm{ppm}$. Size exclusion chromatography (SEC) analysis was performed in THF as solvent at a flow rate of $1 \mathrm{~mL} \cdot \mathrm{min}^{-1}$ at $30{ }^{\circ} \mathrm{C}$. The apparatus was equipped with a guard column and PLGel 500,10 ${ }^{3}, 10^{4}$ columns (Polymer Laboratories). The molecular weight calibration curve was determined using poly(methyl methacrylate) (PMMA) standards from Polymer Laboratories. Differential scanning calorimetry (DSC) analysis was carried out on a Mettler Toledo apparatus with 5-10 mg of product. Samples were heated at $10 \mathrm{~mL} \cdot \mathrm{min}^{-1}$ to $150{ }^{\circ} \mathrm{C}$ and cooled at the same rate to ambient temperature. The samples were then heated at $10{ }^{\circ} \mathrm{C} / \mathrm{min}$ from -150 to $100{ }^{\circ} \mathrm{C}$. Mass spectrometry analyses were conducted with a Bruker Ultra-Flex MALDI-TOF mass spectrometer, equipped with a nitrogen laser (LSI, $337 \mathrm{~nm}, 10 \mathrm{~ns}$ pulse length) and one detector. Mixture of peptides was used for external calibration. The ions were accelerated by a potential of $25 \mathrm{kV}$ and reflected with a $26.3 \mathrm{kV}$ potential. All measurements were recorded in the reflection mode using R-cyano-4-hydroxycinamic acid (HCCA) as matrix with NaI. For 
each spectrum 300 transients were accumulated. The polymer was dissolved in acetonitrile at a concentration of $10 \mathrm{mg} \cdot \mathrm{mL}^{-1}$. Critical Aggregation Concentration (CAC) was determined by tensiometry using the du Noüy method with a tensiometer (Lauda TD2) fitted with a platinum ring with a total contact length of $0.08 \mathrm{~m}$. Both the ring and the glass sample dish were cleaned thoroughly with acetone, 5 mol. $\mathrm{L}^{-1}$ nitric acid, and deionized water and dried overnight before use. The surface tension of water was checked to be $72 \mathrm{mN} \mathrm{N}^{-\mathrm{N}}$. Stock COx solutions were prepared and aliquots were added to deionised water to give desired concentrations. The data were modeled using the Gibbs adsorption isotherm, which relates the surface excess (inversely proportional to the area per molecule) to the variation of the surface tension with concentration:

$$
\begin{aligned}
& \Gamma=-\frac{1}{m R T} \frac{\partial \gamma}{\partial \ln C} \\
& A_{C M C}=\frac{1}{\Gamma_{C M C} N_{A}}
\end{aligned}
$$

Where $\Gamma$ is the surface excess, $\Gamma_{\mathrm{CMC}}$ the surface excess at the critical micelle concentration $(\mathrm{CMC}), \mathrm{A}_{\mathrm{CMC}}$ the area per molecule at the $\mathrm{CMC}, \mathrm{R}$ the gas constant, $\mathrm{T}$ temperature, $\mathrm{\gamma}$ the surface tension, $\mathrm{C}$ the concentration and $\mathrm{N}_{\mathrm{A}}$ the Avogadro number. The prefactor $\mathrm{m}$ is dependent on the surfactant type and structure, as well as the presence of extra electrolyte in the aqueous phase [18][57]. For non-ionic and zwitterionic surfactants, a value of 1 for the pre-factor has been confirmed [19], [20][58, 59]. The size of micelles in aqueous medium were measured by Zetasizer Nano-ZS (Malvern Instrument Ltd., UK) equipped with a He-Ne laser $(\lambda=632.8 \mathrm{~nm})$. Samples were introduced into the cells (pathway: $10 \mathrm{~mm}$ ) after filtration through $0.2 \mu \mathrm{m}$ pore size Acrodisc filters to determine the hydrodynamic radius of polymer objects in aqueous solutions. The correlation function of DLS was analyzed via the general purposed method (NNLS) to obtain the distribution of diffusion coefficients (D) of the solutes. $\mathrm{D}$ is related to the apparent hydrodynamic radius, $\mathrm{D}_{\mathrm{h}}$, of the solute by the StokesEinstein relation (equation 3): 


$$
D_{h}=\frac{k T}{3 \pi \eta D}
$$

with $\mathrm{k}$ Boltzmann's constant, $\mathrm{T}$ the absolute temperature, and $\eta$ the viscosity of the solvent. Static Light Scattering (SLS) experiments were carried out on a Malvern Autosizer 4800 spectrogoniometer (Malvern Instruments, UK) equipped with a 50-mW laser operating at 532 $\mathrm{nm}$. The static scattered intensities were corrected from pinhole size and normalized respective to toluene. The measurements were taken at $20{ }^{\circ} \mathrm{C}$ over a range of scattering wave vectors $(q=4 \pi n \cdot \sin (\theta / 2) / \lambda$, with $\theta$ being the angle of observation and $n$ the refractive index of the solvent). The Rayleigh ratio, $\mathrm{R}_{\theta}$, was determined using equation 4 ,

$$
R_{\theta}=\frac{I_{\text {solution }}(\theta)-I_{\text {solvent }}(\theta)}{I_{\text {toluene }}(\theta)} \cdot\left(\frac{n_{\text {solvent }}}{n_{\text {tollene }}}\right)^{2} \cdot R_{\text {toluene }}
$$

where $I_{\text {solution, }} I_{\text {solvent }}$ and $I_{\text {toluene }}$ are the scattering intensities of the solution, solvent and reference (toluene) respectively, $\mathrm{n}$ is the refractive index $\left(\mathrm{n}_{\text {water }}=1.333, \mathrm{n}_{\text {toluene }}=1.496\right)$ and $\mathrm{R}_{\text {toluene }}$ the Rayleigh ratio of toluene $\left(\mathrm{R}_{\text {toluene }}=2.54 \times 10^{-5} \mathrm{~cm}^{-1}\right.$ for $\left.\lambda=532 \mathrm{~nm}\right)$. The optical constant, $\mathrm{K}$, is defined by equation 5 , where $\mathrm{N}_{\mathrm{a}}$ is the Avogadro number and $\mathrm{dn} / \mathrm{dC}$ is the incremental refractive index.

$$
K=\frac{4 \pi^{2} n_{\text {solvent }}{ }^{2}}{\lambda^{4} N_{a}}\left(\frac{\partial n}{\partial C}\right)^{2}
$$

In all cases, it was verified that the apparent radius of gyration of the systems verified $\mathrm{q} \times \mathrm{Rg}$ $<$ 1. The Zimm approximation can thus be used to obtain equation 6 . Plotting $\mathrm{KC} / \mathrm{R} \theta$ as a function of $\mathrm{q}^{2}$ for each concentration yielded the apparent radius of gyration $\mathrm{Rg}$ of the scatterers as well as their apparent molecular weight extrapolated to zero angle, $M_{a}$. Representative plots are shown in Figure SI-1 and SI-2.

$$
\frac{K C}{R_{\theta}}=\frac{1}{M_{a}} \cdot\left(1+\frac{q^{2} \cdot R_{g}^{2}}{3}\right)
$$


At a given concentration the Rayleigh ratio, $\mathrm{R}_{\theta}$, is related to the apparent molecular weight of the sample, given by equation 4 . It is only at infinite dilutions, where the interactions between scattering particles are negligible, that the apparent molecular weight is equal to the true molecular weight.[60] Multiple concentrations were measured and a plot of linear regression was used to determine the apparent molecular weight at a concentration of $0 \mathrm{mg} \cdot \mathrm{mL}^{-1}$.

\section{Synthesis of chloroacetylated cardanol initiator (CIn)}

The reaction between cardanol and chloroacetylchloride achieved in a tricol equipped with a condenser. Cardanol, triethylamine (1.1 eq) and anhydrous dichloromethane were mixed and cooled down in an ice bath and left under dry nitrogen stream. A solution of chloroacetyl chloride (1.5 eq) in dichloromethane was added dropwise. The reaction was completed after stirring at $0{ }^{\circ} \mathrm{C}$ during $30 \mathrm{~min}$ and the product was purified by washing the organic part with brine (EtOAc/brine) several times (yield: 98\%).

${ }^{1} \mathrm{H}$ NMR $\left(300 \mathrm{MHz}, \mathrm{CDCl}_{3}\right): 7.3\left(\mathrm{H}_{\mathrm{j}}, \mathrm{dd}\right), 7.1\left(\mathrm{H}_{\mathrm{k}}, \mathrm{d}\right), 7.0-6.9\left(\mathrm{H}_{\mathrm{l}}, \mathrm{m}\right), 5.8\left(\mathrm{H}_{\mathrm{i}}, \mathrm{m}\right)$, 5.5-5.25 $\left(\mathrm{H}_{\mathrm{h}}, \mathrm{m}\right)$, 5.15-5.0 $\left(\mathrm{H}_{\mathrm{g}}, \mathrm{m}\right), 4.25\left(\mathrm{H}_{\mathrm{y}}, \mathrm{s}\right), 2.8\left(\mathrm{H}_{\mathrm{f}}, \mathrm{m}\right), 2.6\left(\mathrm{H}_{\mathrm{e}}, \mathrm{t}\right), 2.0\left(\mathrm{H}_{\mathrm{d}}, \mathrm{m}\right), 1.6\left(\mathrm{H}_{\mathrm{c}}, \mathrm{m}\right), 1.3$ $\left(\mathrm{H}_{\mathrm{b}}, \mathrm{m}\right), 0.9\left(\mathrm{H}_{\mathrm{a}}, \mathrm{m}\right)$.

\section{CROP of 2-methyl-2-oxazoline using CIn}

$\mathrm{NaI}$ (1 eq) in dry acetonitrile was added dropwise to a $0.5 \mathrm{M}$ solution of $\mathrm{CIn}$ in dry acetonitrile. The mixture was vigorously stirred 2 hours at room temperature before adding MOx. The monomer concentration in the final mixture was inferior to $4 \mathrm{M}$. The solution was stirred at $78{ }^{\circ} \mathrm{C}$ during 24 hours. At the end of the reaction, the mixture was quenched by addition of an adequate amount of piperidine (5 eq in respect to CIn) and stirred during 30 
min at $40^{\circ} \mathrm{C}[61]$. After cooling, the polymer was isolated by 3 successive precipitations from cold diethyl ether.

${ }^{1} \mathrm{H}$ NMR $\left(300 \mathrm{MHz}, \mathrm{CDCl}_{3}\right): 7.3\left(\mathrm{H}_{\mathrm{j}}, \mathrm{dd}\right), 7.1\left(\mathrm{H}_{\mathrm{k}}, \mathrm{d}\right), 7.0-6.9\left(\mathrm{H}_{\mathrm{l}}, \mathrm{m}\right), 5.8\left(\mathrm{H}_{\mathrm{i}}, \mathrm{m}\right)$, 5.5-5.25 $\left(\mathrm{H}_{\mathrm{h}}, \mathrm{m}\right)$, 5.15-5.0 $\left(\mathrm{H}_{\mathrm{g}}, \mathrm{m}\right), 4.5\left(\mathrm{H}_{\mathrm{y}}, \mathrm{s}\right), 4-3.2\left(\mathrm{H}_{4}\right.$ and $\left.\mathrm{H}_{3}, \mathrm{~m}\right), 2.8\left(\mathrm{H}_{\mathrm{f}}, \mathrm{m}\right), 2.6\left(\mathrm{H}_{\mathrm{e}}, \mathrm{t}\right), 2.25\left(\mathrm{H}_{5}\right.$ and $\left.\mathrm{H}_{\mathrm{d}}, \mathrm{m}\right), 1.9\left(\mathrm{H}_{2}, \mathrm{~s}\right), 1.7\left(\mathrm{H}_{1}, \mathrm{~s}\right), 1.6\left(\mathrm{H}_{\mathrm{c}}, \mathrm{m}\right), 1.3\left(\mathrm{H}_{\mathrm{b}}, \mathrm{m}\right), 0.9\left(\mathrm{H}_{\mathrm{a}}, \mathrm{m}\right)$. 


\section{Results and discussion}

\section{Oxazolines polymerized by cationic ring-opening polymerization (CROP). Efficient}

initiators for CROP must have good leaving group with appropriate nucleophilicity such as Lewis acids, strong protic acids and their corresponding esters, alkylhalides [62] or molecular iodine [63]. These aspects have been largely investigated by different authors who studied the covalent and ionic mechanisms of CROP of 2-R-2-oxazolines [64-73]. The initiators were classified in term of polymerization rate depending on the nucleophilicity of the counterions MeOTf $>$ MeOTs $>$ MeI $>$ benzyl bromide $[74,75]$. The initiation of the polymerization of oxazolines by chlorinated compounds is limited and only low monomer conversions are reached. To solve this problem, an in situ conversion of $\mathrm{CH}_{2}-\mathrm{Cl}$ into $\mathrm{CH}_{2}$ - $\mathrm{I}$ is often considered. Indeed, the weaker C-I bond improves the initiation of the polymerization by an ionic mechanism via an oxazolinium species with $\mathrm{I}^{-}$as counter-anion.

Herein, the CROP of 2-methyl-2-oxazoline (MOx) occurred using bio-based initiator, and more specifically, a phenolic lipid named cardanol as illustrated in Figure 2. By ${ }^{1} \mathrm{H}$ NMR spectroscopy, the cardanol composition was calculated knowing that it is a singular lipidic derivative bearing an uneven number of carbon atoms on saturated (C15:0), mono- (C15:1), di- (C15:2) and tri-unsaturated alkyl chains (C15:3) (unsaturations under trans configuration) (Figure 1). From $\mathrm{H}_{h}, \mathrm{H}_{\mathrm{i}}$ and $\mathrm{H}_{\mathrm{g}}$ signals, $49.7 \%$ of $\mathrm{C} 15: 3$ were calculated while $12.4 \%$ of C15:2 and 37.3\% of C15:1 were estimated from $\mathrm{H}_{\mathrm{g}}$ and aforementioned signals (Figure 3). We noted only $0.6 \%$ of saturated chains of $\mathrm{C} 15: 0$ considering $\mathrm{H}_{\mathrm{a}}$ signal. Finally, cardanol owns 2.1 unsaturations in average per chain.

First, cardanol was converted into chlorinated initiator (CIn) by esterification with chloroacetyl chloride. The trans-halogenation of CIn into the corresponding more reactive iodinated initiator was undertaken in an one step CROP process before adding MOx monomer 
without any isolation of the initiator. The optimized conditions of trans-halogenation have already been described [49].

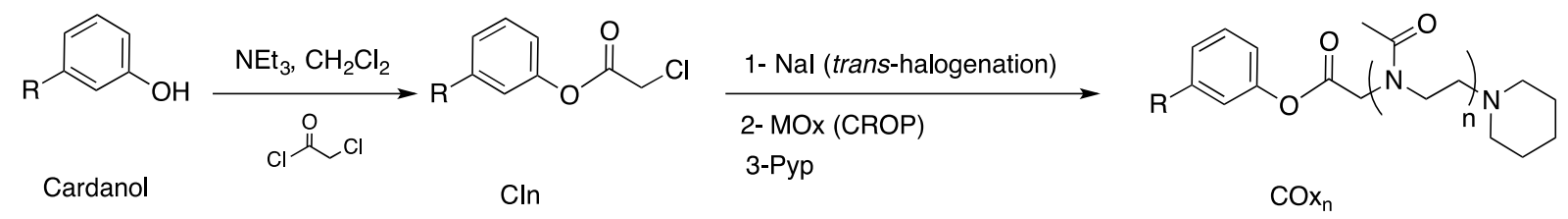

Figure 2. Synthetic route towards amphiphilic polymers $\mathrm{COx}_{\mathrm{n}}$ using CIn initiator.

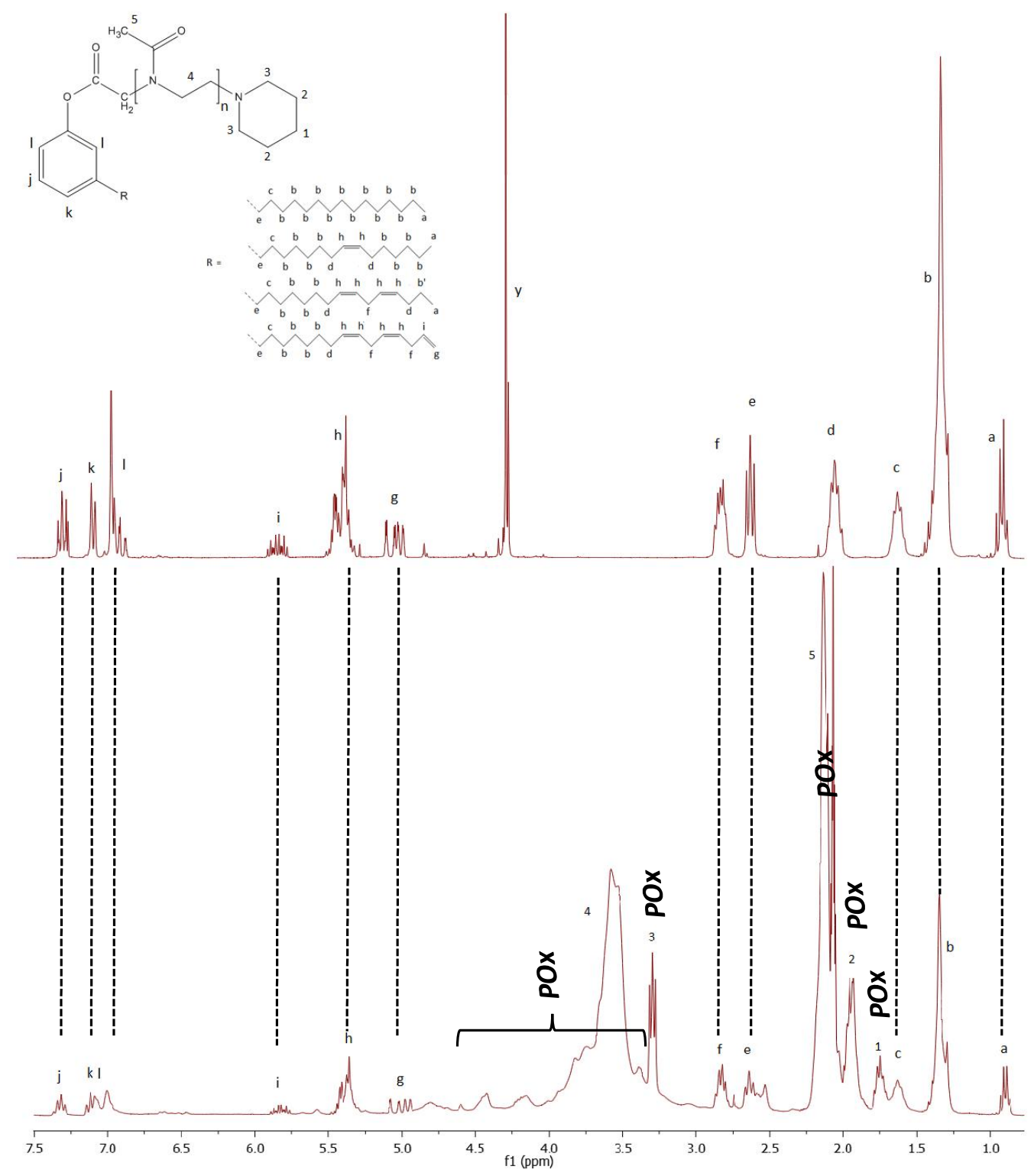

Figure 3. ${ }^{1} \mathrm{H}$ NMR spectra of $\mathrm{CIn}$ and $\mathrm{COx}_{\mathrm{n}}$ in $\mathrm{CDCl}_{3}$. 
In ${ }^{1} \mathrm{H}$ NMR spectrum of $\mathrm{COx}_{\mathrm{n}}$, the characteristic signals of cardanol aromatic ring (7.5-7.0 ppm) and alkyl chain (unsaturations in the 6.0-5.0 ppm region and terminal $\mathrm{CH}_{3}$ group at 0.9 ppm) were detected as well as those of POx located at around 2.0 and $3.5 \mathrm{ppm}$ (Figure 3). The integration of $\mathrm{CH}_{2}$ POx signal (after deduction of $\mathrm{H}_{3}$ ) related to $\mathrm{H}_{\mathrm{j}}$ (for instance) gave the degree of polymerization $\left(\mathrm{DP}_{\mathrm{n}}, \mathrm{NMR}\right)$. Thus, various amphiphilic POx oligomers were produced with a degree of polymerization ranging from 11 to 27 corresponding to a molar molecular weight of 1440-2720 g. $\mathrm{mol}^{-1}$ as summarized in Table 1 and illustrated in Figure SI3 with the GPC traces. We noted the predominance of hydrophilic behavior of these nonionic surfactants with a hydrophilic/hydrophobic ratio between 4.1 to 8.7 using the molecular weight of each part of the amphiphilic molecule.

Table 1. Characteristics of $\mathrm{COx}_{\mathrm{n}}$ and $\mathrm{C}_{\mathrm{m}}$-POx nonionic surfactants.

\begin{tabular}{|c|c|c|c|c|c|c|}
\hline & $\begin{array}{c}\text { Alkyl } \\
\text { chain }\end{array}$ & $\mathrm{DP}_{\text {POx }}{ }^{\mathrm{a}}$ & $\begin{array}{c}\mathrm{M}_{\mathrm{n}}{ }^{\mathrm{a}} \\
(\mathrm{g} / \mathrm{mol})\end{array}$ & $\begin{array}{c}\mathrm{M}_{\text {philic }}{ } \\
\mathrm{M}_{\text {phobic }}{ }^{\mathrm{b}}\end{array}$ & $\begin{array}{c}\mathrm{CAC}^{\mathrm{c}} \\
(\mathrm{mg} / \mathrm{L})\end{array}$ & $\mathrm{CAC}^{\mathrm{c}}$ \\
\hline $\mathrm{C}_{12}-\mathrm{POx}_{13}$ & $12: 0$ & 13 & 1300 & 6.6 & 13.1 & 10.2 \\
\hline $\mathrm{C}_{12}-\mathrm{POx}_{25}$ & $12: 0$ & 25 & 2300 & 12.7 & 29.1 & 12.6 \\
\hline $\mathrm{C}_{12}-\mathrm{POx}_{33}$ & $12: 0$ & 33 & 3075 & 16.7 & 61.5 & 20.0 \\
\hline $\mathrm{COx}_{11}$ & $15: 2.1$ & 11 & 1360 & 4.8 & 5.3 & 4.1 \\
\hline $\mathrm{COx}_{14}$ & $15: 2.1$ & 14 & 1615 & 5.7 & 23.5 & 12.0 \\
\hline $\mathrm{COx}_{24}$ & $15: 2.1$ & 24 & 2460 & 8.7 & 32.9 & 13.7 \\
\hline $\mathrm{COx}_{28}$ & $15: 2.1$ & 28 & 2800 & 10 & 45.8 & 17.0 \\
\hline $\mathrm{C}_{18}-\mathrm{POx}_{25}$ & $18: 0$ & 25 & 2400 & 8.5 & 19.1 & 7.95 \\
\hline
\end{tabular}

${ }^{\mathrm{a}}$ : values determined by ${ }^{1} \mathrm{H}$ NMR spectroscopy.

${ }^{\mathrm{b}}: \mathrm{M}_{\text {philic }}=85 \times \mathrm{DP}_{\mathrm{n}}+\mathrm{M}_{\text {piperine }}(84 \mathrm{~g} / \mathrm{mol})+\mathrm{M}_{(\mathrm{O}-\mathrm{CO}-\mathrm{CH} 2)}(58 \mathrm{~g} / \mathrm{mol}) . \mathrm{M}_{\text {phobic }}=283 \mathrm{~g} / \mathrm{mol}$.

${ }^{c}$ : values determined by tensiometry. 
MALDI-TOF mass spectroscopy confirmed the nature of the POx end-groups and the success of CROP process. The theoretical values were compared to the experimental ones (M, RM and $\Delta \mathrm{M})$ as summarized in Table 2 . The theoretical masses were expressed following equation 7:

$$
\mathrm{M}_{\mathrm{th}}=\Delta \mathrm{M}_{\mathrm{th}} \times \mathrm{n}+\mathrm{RM}_{\mathrm{th}}
$$

where $\mathrm{M}_{\mathrm{th}}$ is the calculated mass of the polymer of degree of polymerization nearest to the measured value, $\Delta \mathrm{M}_{\mathrm{th}}$ is the mass of the monomer unit, and $\mathrm{RM}_{\mathrm{th}}$ represents the calculated residual mass. The $\mathrm{M}_{\mathrm{p}}$ values (mass peak corresponding to the maximum of the population) and the number average molecular weight $\left(\mathrm{M}_{\mathrm{n}}\right)$ are also given in Table 2. The POx chemical structure $\left(\mathrm{COx}_{11}\right)$ was analyzed after the termination stage by piperidine (Figure 2). The interval between two consecutive peaks was $85.05 \mathrm{~g} / \mathrm{mol}$ corresponding to the molecular weight of MOx monomeric unit as illustrating in the Maldi-Tof spectrum zoom of Figure SI4. As expected, the detected family corresponding to POx structure initiated by CIn and terminated by piperidine associated to $\mathrm{Na}^{+}$counter-ion $\left(\mathrm{MNa}^{+}\right.$type) predominates related to the minority $\mathrm{MH}^{+}$family (Figure 4$)$. The main $\mathrm{m} / \mathrm{z}$ population ranged from $511\left(\mathrm{n}=1 ; \mathrm{COx}_{1}\right)$ to $2723 \mathrm{Da}\left(\mathrm{n}=27, \mathrm{COx}_{27}\right)$. We noted that the number average molecular mass deduced by GPC was consistent with that of Maldi-Tof, 1360 and $1191 \mathrm{~g} / \mathrm{mol}$, respectively. 


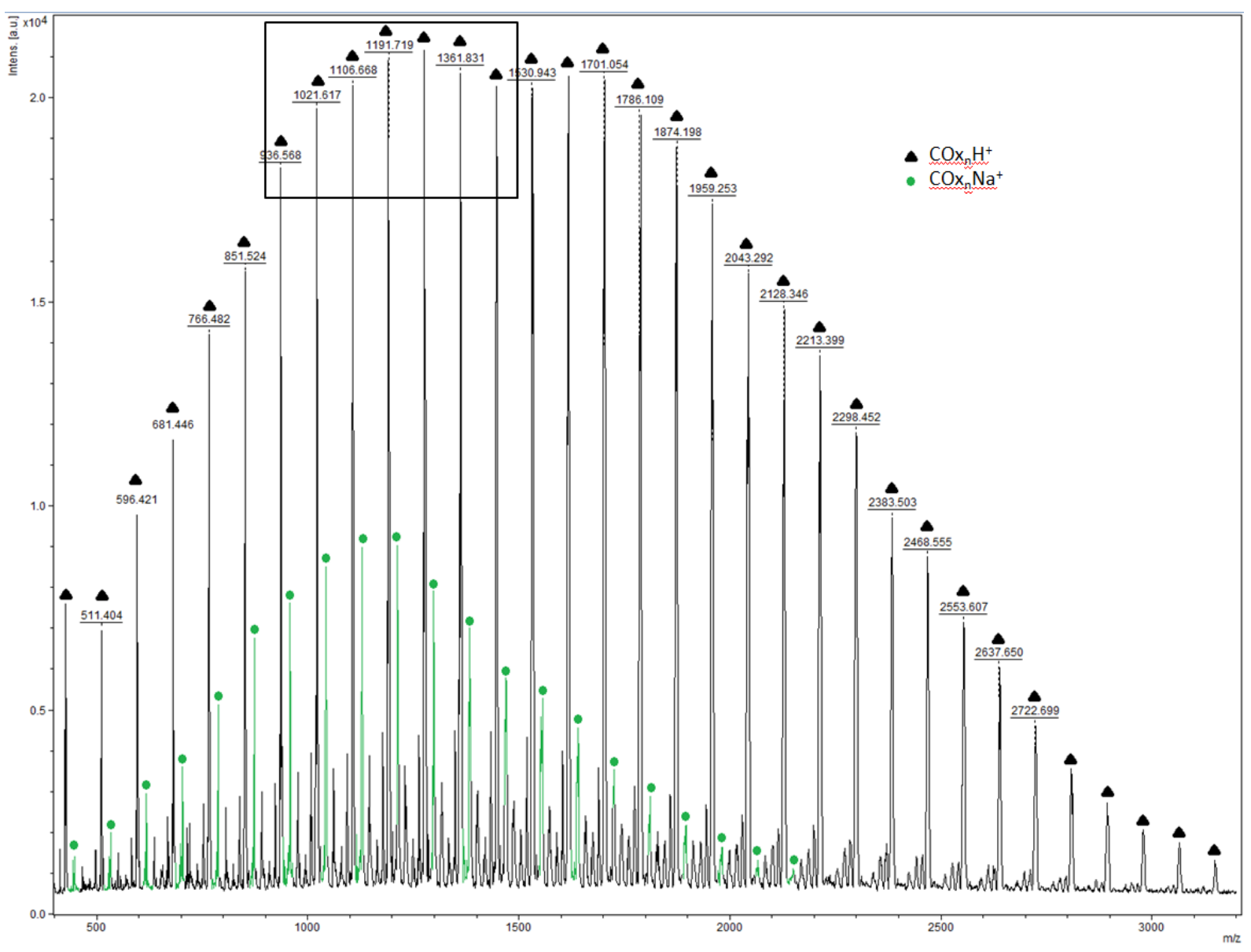

Figure 4. Maldi-Tof spectrum of $\mathrm{COx}_{11}$.

Table 2. Analytical Data Derived from $\mathrm{COx}_{11}$ MALDI-TOF MS Spectroscopy.

\begin{tabular}{|c|c|c|c|c|c|c|c|}
\hline $\begin{array}{c}\text { Assignemen } \\
\mathrm{t}\end{array}$ & $\mathrm{RM}_{\text {formula }}{ }^{\mathrm{a}}$ & $\mathrm{DM}_{\exp }{ }^{\mathrm{a}}$ & $\mathrm{RM}_{\mathrm{th}}{ }^{\mathrm{a}}$ & $\mathrm{RM}_{\exp }{ }^{\mathrm{a}}$ & $\mathrm{M}_{\mathrm{p}, \mathrm{th}}{ }^{\mathrm{a}}$ & $\mathrm{M}_{\mathrm{p}, \exp }{ }^{\mathrm{a}}$ & Calculation \\
\hline $\mathrm{COx}_{\mathrm{n}}$ & $\mathrm{C}_{32} \mathrm{H}_{50} \mathrm{~N}_{2}$ & 85.05 & 425.28 & 425.37 & 1191.18 & 1191.72 & $85.10 n+$ \\
& $\mathrm{O}_{3}$ & & & & & & $\mathrm{RM}$ \\
\hline
\end{tabular}

${ }^{\mathrm{a}}$ Value expressed in g.mol ${ }^{-1}$. 


\section{Self-organization of $\mathrm{COx}_{\mathrm{n}}$}

The Critical Aggregation Concentration (CAC) of the nonionic surfactants $\mathrm{COx}_{\mathrm{n}}$ was determined by tensiometry to estimate their surfactant properties in water (Figure SI-5). For a better understanding of the aromatic ring influence on $\mathrm{COx}_{\mathrm{n}}$ surfactant properties, a supplementary series of linear nonionic surfactants, $\mathrm{C}_{12}-\mathrm{POx}_{\mathrm{n}}$ and $\mathrm{C}_{18}-\mathrm{POx}_{\mathrm{n}}$, were synthesized by using 1-iodododecane and 1-iodooctadecane initiators, respectively as previously reported [76]. The length of the POx hydrophilic block, the hydrophilic/hydrophobic ratio and the CAC values of the nonionic surfactants were gathered in Table 1 . The CAC values of $\mathrm{COx}_{\mathrm{n}}$ are of the same magnitude order than $\mathrm{C}_{12}-\mathrm{POx}_{\mathrm{n}}$ and $\mathrm{C}_{18}-\mathrm{POx}_{\mathrm{n}}$, ranging from 4 to $20 \mu \mathrm{mol} / \mathrm{L}$. Moreover, for $\mathrm{C}_{12}-\mathrm{POx}_{\mathrm{n}}$ and $\mathrm{COx}_{\mathrm{n}}$, the $\mathrm{CAC}$ values increase, as expected, with the length of the hydrophilic chain, represented in Table 1 by the $\mathrm{DP}_{\mathrm{n}}$, NMR and shown in Figure 5 and Figure SI-6. Otherwise, for $\mathrm{DP}_{25}$, the $\mathrm{CAC}$ values were compared in function of the length of the hydrophobic chain. We observed an expected lower value for $\mathrm{C}_{18}-\mathrm{POx}_{25}$ than $\mathrm{C}_{12}-\mathrm{POx}_{25}$ while $\mathrm{COx}_{24}$ has a similar behavior than $\mathrm{C}_{12}-\mathrm{POx}_{25}$.

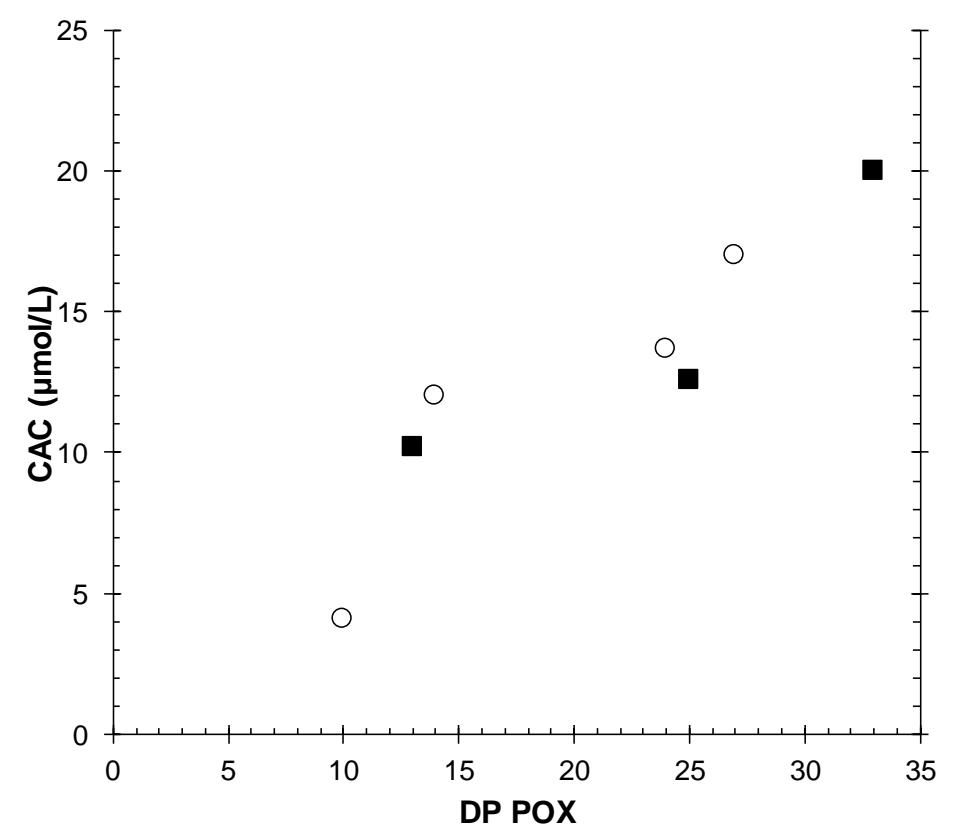

Figure 5. Evolution of CAC value of surfactants in function of $\mathrm{DP}_{\mathrm{n}}$ of the POx moiety of ( $\left.\mathbf{\square}\right)$

$$
\mathrm{C}_{12}-\mathrm{POx}_{\mathrm{n}} \text { and (o) } \mathrm{COx}_{\mathrm{n}}
$$


The surface tensions of $\mathrm{COx}_{\mathrm{n}}$ in water were ranging from 41.0 to $53.0 \mathrm{mN} . \mathrm{m}^{-1}$ (Table 3). From these data, the cross-sectional area of 26,84 , and $95 \AA^{2}$ of $\mathrm{COx}_{11}, \mathrm{COx}_{14}$, and $\mathrm{COx}_{28}$ respectively were calculated and gathered in Table 3. Similarly to previous work on triglyceride functionalized with POx, an increase of the surface of the head group is observed with increasing the $\mathrm{DP}_{\mathrm{n}}$ of the POx moiety.[50] Interestingly, $\mathrm{COx}_{11}\left(26 \AA^{2}\right)$ exhibits a much lower head group surface area than CO-POx $10\left(88 \AA^{2}\right)$, a triglyceride functionalized with a POx moiety of similar $\mathrm{DP}_{\mathrm{n}}$.

Table 3. CAC values, maximum values of the surface excess concentration and surfactant head group surface area determined by tensiometry.

\begin{tabular}{ccccc}
\hline & $\begin{array}{c}\mathrm{CAC} \\
(\mu \mathrm{mol} / \mathrm{L})\end{array}$ & $\begin{array}{c}\mathrm{YCAC}_{\mathrm{CAC}} \\
\left(\mathrm{mN}^{-1}\right)\end{array}$ & $\begin{array}{c}\Gamma_{\mathrm{CAC}} \\
\left(\mu \mathrm{mol} . \mathrm{m}^{-2}\right)\end{array}$ & $\begin{array}{c}\text { Head group } \\
\text { surface area }\left(\AA^{2}\right)\end{array}$ \\
\hline $\mathrm{COx}_{11}$ & 4.1 & 41.2 & 6.46 & 26 \\
$\mathrm{COx}_{14}$ & 12.0 & 52.8 & 1.98 & 84 \\
$\mathrm{COx}_{28}$ & 17.0 & 46.7 & 1.76 & 95
\end{tabular}

The influence of the size of the surfactant hydrophilic chain on the self-assembly in water was investigated on $\mathrm{COx}_{11}, \mathrm{COx}_{14}, \mathrm{COx}_{24}$ and $\mathrm{COx}_{28}$, directly solubilized in water (ultra pure MilliQ). In a preliminary study, the auto-correlation functions were measured at $173^{\circ}$ between 2.5 and $10 \mathrm{~g} / \mathrm{L}$ and exhibited monomodal and quite narrow exponential decays (Figure SI-7). On the other hand, no signal could be observed in chloroform (a good solvent of both blocks), showing that the aggregation came only from the amphiphilic nature of the systems. At $5 \mathrm{~g} / \mathrm{L}$, the calculated values of $\mathrm{D}_{\mathrm{h}}$ were $11.7,15.7,21.0$, and $24.4 \mathrm{~nm}$ respectively (Table 4 ). A clear increase of $\mathrm{D}_{\mathrm{h}}$ with the degree of polymerization of the POx block was observed. For the longest POx block $\left(\mathrm{COx}_{24}\right.$ and $\left.\mathrm{COx}_{28}\right)$, a high $\mathrm{D}_{\mathrm{h}}$ was measured related to $\mathrm{C}_{12}-\mathrm{POx}_{25}(8.4$ $\mathrm{nm})$, CoumPOx $25(9.9 \mathrm{~nm})$ and $\mathrm{C}_{18}-\mathrm{POx}_{25}(10.8 \mathrm{~nm})$ as previously described.[77] This 
discrepancy of $D_{h}$ cannot be justified by a difference of POx length knowing that the persistence length is around $2.0 \mathrm{~nm}$ as previously calculated by Volet et al. considering semiflexible chain for worm-like micelle model.[76] Nevertheless, a similar value $(24.0 \mathrm{~nm})$ has already been reported for a POx bearing a crowded triglyceride hydrophobic structure.[51] We checked by differential scanning calorimetry the absence of a melting point corresponding to $\pi-\pi$ stacking of aromatic rings in the hydrophobic nanoparticle core. A glass transition at only $18{ }^{\circ} \mathrm{C}$ for $\mathrm{DP}_{11}$ and around $30{ }^{\circ} \mathrm{C}$ for $\mathrm{DP}_{14}, \mathrm{DP}_{24}$ and $\mathrm{DP}_{28}$ was detected. In our case, the fatty chain of cardanol acts as a plasticizer regarding the Tg value of poly(2-methyl-2oxazoline) at $80^{\circ} \mathrm{C}[78]$ and that of raw cardanol at $-97^{\circ} \mathrm{C}$ (Figure SI-8).

Complementary experiments of static light scattering were realized on these systems in order to determine the number of aggregation $\left(\mathrm{N}_{\mathrm{agg}}\right)$ of the self-assemblies in aqueous media (concentrations ranging from 2.5 to $10 \mathrm{~g} / \mathrm{L}$ ). This parameter corresponds to the $\mathrm{M}_{\mathrm{w}}$ of the selfassembly, calculated by extrapolation of the apparent molar mass to zero concentration (Figure SI-9) divided by the molar mass of the block copolymer determined by SEC measurement as summarized in Table 4 . Whatever the concentration, the scattering intensity did not depend on the scattering wave vector, indicating that the aggregates were small $\left(\mathrm{R}_{\mathrm{g}}<\right.$ $20 \mathrm{~nm}$ Figure SI-1). The $\mathrm{N}_{\mathrm{agg}}$ values were between 32 and 57. Figure 6 put in evidence a crescent linear relationship between the length of POx chains and the $D_{h}$ of the selfassemblies while the $\mathrm{N}_{\text {agg }}$ values were separated in two regions with the smaller values for the longer POx chains $\left(\mathrm{DP}_{24}\right.$ and $\left.\mathrm{DP}_{28}\right)$. In general, the increase of $\mathrm{N}_{\mathrm{agg}}$ was explained by the need for the stabilization of hydrophobic block of the surfactant in water. Nevertheless, this magnitude of $\mathrm{N}_{\text {agg }}$ has previously been described for other amphiphilic polyoxazolines but in general for smaller nanoparticles.[77] Large nanoparticle with a low $\mathrm{N}_{\mathrm{agg}}$ can only be interpreted by the partial hydration of the core with a vague core-shell delimitation. 
Table 4. Characteristics of $\mathrm{COx}_{\mathrm{n}}$ self-assembly in water.

\begin{tabular}{|c|c|c|c|c|}
\hline $\mathrm{DP}_{\mathrm{POx}}$ & $\begin{array}{c}\mathrm{M}_{\mathrm{w}} \text { self-assembly }{ }^{\mathrm{a}} \\
(\mathrm{g} / \mathrm{mol})\end{array}$ & $\mathrm{M}_{\mathrm{w}}$ unimer $^{\mathrm{b}}(\mathrm{g} / \mathrm{mol})$ & $\mathrm{N}_{\mathrm{agg}}$ & $\begin{array}{l}\mathrm{D}_{\mathrm{h}}{ }^{\mathrm{a}} \\
(\mathrm{nm})\end{array}$ \\
\hline 11 & 77700 & 1443 & 54 & 11.7 \\
\hline 14 & 83000 & 1953 & 58 & 15.7 \\
\hline 24 & 87600 & 2378 & 32 & 21.0 \\
\hline 28 & 100700 & 2718 & 37 & 24.4 \\
\hline
\end{tabular}

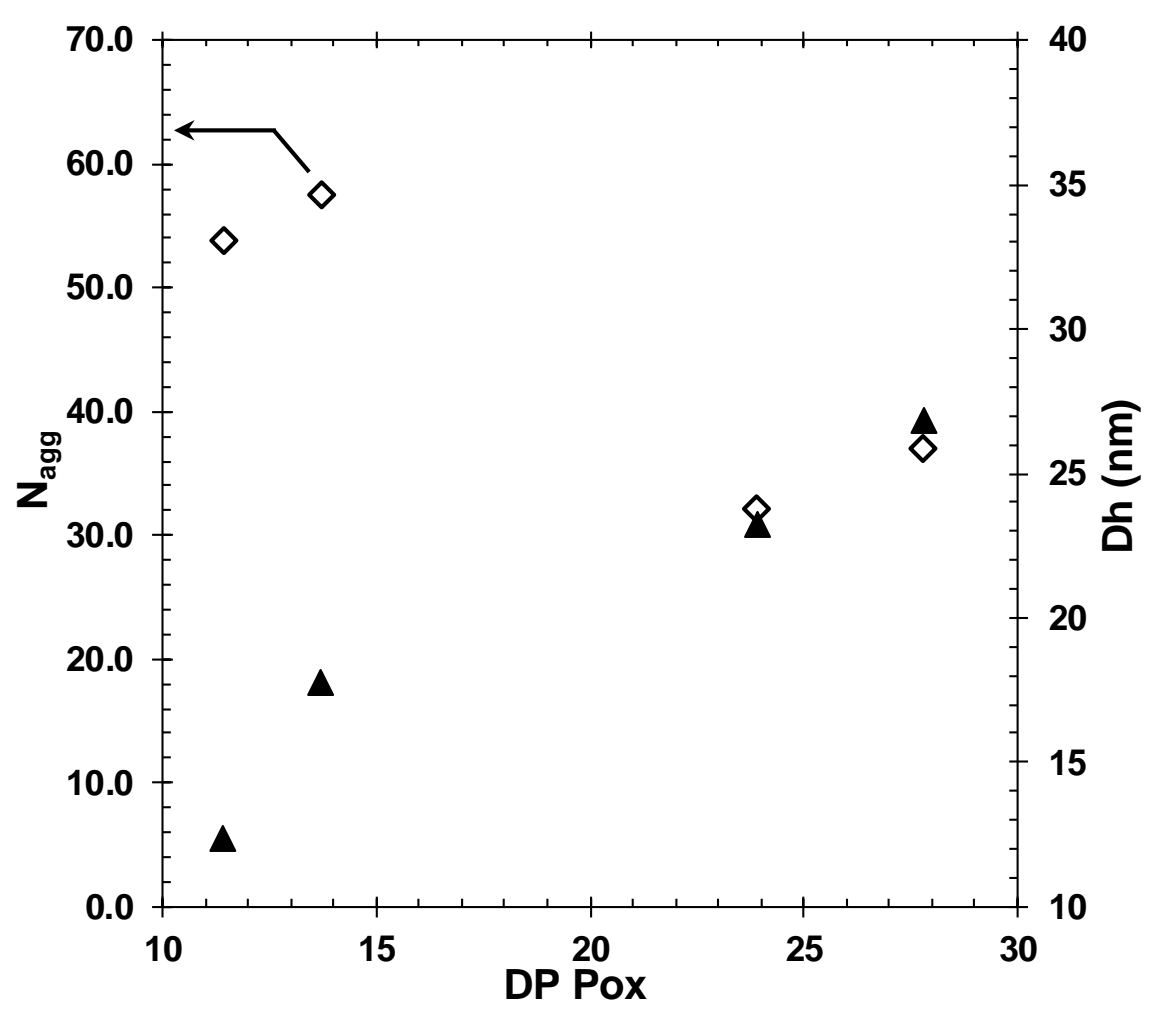

Figure 6. Evolution of the number of aggregation (Nagg) $(\diamond)$ and the hydrodynamic diameter $(\mathrm{Dh})(\boldsymbol{\Delta})$ of various $\mathrm{Cx}_{\mathrm{n}}$ as a function of the degree of polymerization of the POx moiety. 


\section{Conclusion}

An alternative to nonyl phenol ethoxylate (NPE) surfactants is described using cardanol as bio-based phenolic building block and polyoxazoline as PEO alternative. The control of the CROP process permits the synthesis of well-defined linear alkyl benzene (LAB) surfactants $\left(\mathrm{COx}_{\mathrm{n}}\right)$ as evidenced by NMR and Maldi-tof spectroscopies. The surfactant properties of the nonionic surfactants evolved with the hydrophilic-hydrophobic balance between the length of the POx chain and the lipidic cardanol ring. The investigation of their behavior in water was monitored by dynamic and static light scattering experiments and the size and the composition of the self-assemblies were precisely estimated. In a future study, we will investigate the biodegradability and the toxicity in aquatic environment of these LAB surfactants knowing the toxicity in NPE decreases with the length of the PEO chain and that the meta position in benzene such as in cardanol ring, favors the degradation of the molecule.

\section{Acknowledgments}

We thank Corine Gerardin for SLS experiments, and Gilles Valette for Maldi-Tof experiments. 


\section{References}

1. Ghosh, B. and A.D. Jones, Profiling, characterization, and analysis of natural and synthetic acylsugars (sugar esters). Analytical Methods, 2017. 9(6): p. 892-905.

2. Paulino, B.N., et al., Current status in biotechnological production and applications of glycolipid biosurfactants. Applied Microbiology and Biotechnology, 2016. 100(24): p. 10265-10293.

3. Gedam, P.H. and P.S. Sampathkumaran, Cashew nut shell liquid - extraction, chemistry and applications. Progress in Organic Coatings, 1986. 14(2): p. 115-157.

4. Voirin, C., et al., Functionalization of cardanol: towards biobased polymers and additives. Polymer Chemistry, 2014. 5(9): p. 3142-3162.

5. Balachandran, V.S., et al., Recent advances in cardanol chemistry in a nutshell: from a nut to nanomaterials. Chemical Society Reviews, 2013. 42(2): p. 427-438.

6. Ambrozic, R., U. Sebenik, and M. Krajnc, Epoxy emulsions stabilized with reactive bio-benzoxazine surfactant from epoxidized cardanol for coatings. European Polymer Journal, 2016. 81: p. 138-151.

7. Peungjitton, P., et al., Sodium Cardanol Sulfonate Surfactant from Cashew Nut Shell Liquid. Journal of Surfactants and Detergents, 2009. 12(2): p. 85-89.

8. $\quad$ Phulkerd, P., et al., Coal water slurry using dispersant synthesized from cashew nut shell liquid (CNSL). Fuel Processing Technology, 2014. 119: p. 256-262.

9. Anilkumar, P. and M. Jayakannan, Self-Assembled Cylindrical and Vesicular Molecular Templates for Polyaniline Nanofibers and Nanotapes. Journal of Physical Chemistry B, 2009. 113(34): p. 11614-11624.

10. Castro Dantas, T., et al., Micellization study and adsorption properties of an ionic surfactant synthesized from hydrogenated cardanol in air-water and in air-brine interfaces. Colloid and Polymer Science, 2009. 287(1): p. 81-87.

11. Cheng, C.J., et al., UV cured polymer based on a renewable cardanol derived RAFT agent. Journal of Polymer Research, 2013. 20(7).

12. Kattimuttathu, S.I., et al., Synthesis and Micellization Properties of New Anionic Reactive Surfactants Based on Hydrogenated Cardanol. Journal of Surfactants and Detergents, 2012. 15(2): p. 207-215.

13. Barreto, A.C.H., et al., Novel ferrofluids coated with a renewable material obtained from cashew nut shell liquid. Microfluidics and Nanofluidics, 2012. 12(5): p. 677-686.

14. Scorzza, C., et al., Synthesis and Physicochemical Characterization of Anionic Surfactants Derived from Cashew Nut Shell Oil. Journal of Surfactants and Detergents, 2010. 13(1): p. 27-31.

15. Faye, I., et al., Sustainable cardanol-based ionic surfactants. Green Materials, 2017. 5(3): p. 144-152.

16. Darroman, E., et al., New aromatic amine based on cardanol giving new biobased epoxy networks with cardanol. European Journal of Lipid Science and Technology, 2015. 117(2): p. 178-189.

17. Wang, R., et al., Syntheses of cardanol-based cationic surfactants and their use in emulsion polymerisation. Chemical Papers, 2016. 70(9): p. 1218-1227.

18. Puchot, L., et al., Tailoring the reactivity of bio-surfactants as a tool for montmorillonite exfoliation in epoxy thermosets. Applied Clay Science, 2014. 99: p. $35-41$.

19. Verge, P., et al., Organomodification of sepiolite clay using bio-sourced surfactants: Compatibilization and dispersion into epoxy thermosets for properties enhancement. Composites Science and Technology, 2013. 79: p. 126-132. 
20. Ahire, M.B. and S.S. Bhagwat, Novel Ester-linked Anionic Gemini Surfactant: Synthesis, Surface-Active Properties and Antimicrobial Study. Journal of Surfactants and Detergents, 2017. 20(4): p. 789-797.

21. Li, C.Q., et al., Interface Activity and Thermodynamic Properties of Cardanol Polyoxyethylene Ether Carboxylates. Tenside Surfactants Detergents, 2016. 53(4): p. 304-312.

22. Luan, H.X., et al., Study on Cardanol betaine Surfactants for Ultralow Interfacial Tension in a Low Range of Surfactant Concentration and Wide Range of Temperature Applied in Compound Flooding. Tenside Surfactants Detergents, 2015. 52(1): p. 2934.

23. Zhou, Y.W., et al., Synthesis and Characterization of Saturated Cardanol Sulfonate Salt Gemini Surfactant. Tenside Surfactants Detergents, 2017. 54(4): p. 322-326.

24. Bhadani, A., H. Kataria, and S. Singh, Synthesis, characterization and comparative evaluation of phenoxy ring containing long chain gemini imidazolium and pyridinium amphiphiles. Journal of Colloid and Interface Science, 2011. 361(1): p. 33-41.

25. Tyman, J.H.P. and I.E. Bruce, Synthesis and characterization of polyethoxylate surfactants derived from phenolic lipids. Journal of Surfactants and Detergents, 2003. 6(4): p. 291-297.

26. Tyman, J.H.P. and I.E. Bruce, Surfactant properties and biodegradation of polyethoxylates from phenolic lipids. Journal of Surfactants and Detergents, 2004. 7(2): p. 169-173.

27. Nowicka, D., et al., Biodegradation of oxyethylated fatty alcohols by bacteria Microbacterium strain E19. Ecotoxicology and Environmental Safety, 2013. 91: p. 32-38.

28. Tomalia, D.A. and D.P. Sheetz, Homopolymerization of 2-alkyl- and 2-aryl-2oxazolines. Journal of Polymer Science Part a-1-Polymer Chemistry, 1966. 4(9PA1): p. 2253-\&.

29. Hoogenboom, R., 50 years of poly(2-oxazoline)s. European Polymer Journal, 2017. 88: p. 448-450.

30. Verbraeken, B., et al., The chemistry of poly(2-oxazoline)s. European Polymer Journal, 2017. 88: p. 451-469.

31. Tauhardt, L., et al., Poly(2-oxazoline) functionalized surfaces: from modification to application. Chemical Society Reviews, 2013. 42(20): p. 7998-8011.

32. Hartlieb, M., et al., Tailoring Cellular Uptake and Fluorescence of Poly(2-oxazoline)Based Nanogels. Bioconjugate Chemistry, 2017. 28(4): p. 1229-1235.

33. Kempe, K., et al., Preparation of non-spherical particles from amphiphilic block copolymers. Journal of Polymer Science Part a-Polymer Chemistry, 2016. 54(6): p. 750-757.

34. Hartlieb, M., K. Kempe, and U.S. Schubert, Covalently cross-linked poly(2-oxazoline) materials for biomedical applications - from hydrogels to self-assembled and templated structures. Journal of Materials Chemistry B, 2015. 3(4): p. 526-538.

35. Tauhardt, L., et al., Amine end-functionalized poly(2-ethyl-2-oxazoline) as promising coating material for antifouling applications. Journal of Materials Chemistry B, 2014. 2(30): p. 4883-4893.

36. Farrugia, B.L., et al., Poly(2-oxazoline) Hydrogels for Controlled Fibroblast Attachment. Biomacromolecules, 2013. 14(8): p. 2724-2732.

37. Kobayashi, S., et al., Block copolymers from cyclic imino ethers - a new class of nonionic polymer surfactant. Macromolecules, 1986. 19(3): p. 535-541.

38. Kempe, K., et al., Poly(2-oxazoline) glycopolymers with tunable LCST behavior. Polymer Chemistry, 2011. 2(8): p. 1737-1743. 
39. Volet, G., et al., Synthesis of monoalkyl end-capped poly(2-methyl-2-oxazoline) and its micelle formation in aqueous solution. Macromolecules, 2005. 38(12): p. 5190-5197.

40. Weberskirch, R. and O. Nuyken, Synthesis and characterization of water-soluble block copolymers with an end-tagged naphthalene probe. Journal of Macromolecular Science-Pure and Applied Chemistry, 1999. A36(5-6): p. 843-857.

41. Miyamoto, M., et al., Preparation of block copolymer consisting of poly(2-methyl-2oxazoline) and poly(propylene oxide) blocks - a new nonionic surfactant. Polymer Journal, 1992. 24(4): p. 405-409.

42. Rayeroux, D., V. Lapinte, and P. Lacroix-Desmazes, One-pot synthesis of amphiphilic diblock copolymers of poly(styrene) and poly(2-methyl-2-oxazoline) by the direct combination of reverse iodine transfer polymerization (RITP) and cationic ringopening polymerization (CROP) processes. Journal of Polymer Science Part aPolymer Chemistry, 2012. 50(22): p. 4589-4593.

43. Chujo, Y., E. Ihara, and T. Saegusa, Synthesis of polyoxazoline polysiloxane block copolymers. Kobunshi Ronbunshu, 1992. 49(11): p. 943-946.

44. Kaberov, L.I., et al., Novel triphilic block copolymers based on poly(2-methyl2oxazoline)-block-poly(2-octyl-2-oxazoline) with different terminal perfluoroalkyl fragments: Synthesis and self-assembly behaviour. European Polymer Journal, 2017. 88: p. 645-655.

45. Mansfeld, U., et al., Tuning the morphology of triblock terpoly(2-oxazoline)s containing a 2-phenyl-2-oxazoline block with varying fluorine content. Soft Matter, 2013. 9(25): p. 5966-5974.

46. El Asmar, A., et al., Tuning the Thermo-Sensitivity of Micellar Systems through a Blending Approach. Macromolecules, 2016. 49(11): p. 4307-4315.

47. Guillerm, B., et al., Well-defined poly(oxazoline)-b-poly(acrylate) amphiphilic copolymers: From synthesis by polymer-polymer coupling to self-organization in water. Journal of Polymer Science Part a-Polymer Chemistry, 2013. 51(5): p. 11181128 .

48. Rotta, J., et al., Synthesis of Amphiphilic Polymers Based on Fatty Acids and GlycerolDerived Monomers - A Study of Their Self-Assembly in Water. Macromolecular Chemistry and Physics, 2014. 215(2): p. 131-139.

49. Stemmelen, M., et al., Synthesis and self-assembly of amphiphilic polymers based on polyoxazoline and vegetable oil derivatives. Polymer Chemistry, 2013. 4(5): p. 14451458.

50. Giardi, C., et al., Nonionic polyoxazoline surfactants based on renewable source: Synthesis, surface and bulk properties. Reactive \& Functional Polymers, 2009. 69(9): p. 643-649.

51. Travelet, C., et al., Amphiphilic copolymers based on polyoxazoline and grape seed vegetable oil derivatives: self-assemblies and dynamic light scattering. Journal of Nanoparticle Research, 2013. 15(6).

52. Volet, G., A.C.L. Deschamps, and C. Amiel, Association of Hydrophobically alpha,omega-End-Capped Poly(2-methyl-2-oxazoline) in Water. Journal of Polymer Science Part a-Polymer Chemistry, 2010. 48(11): p. 2477-2485.

53. Lee, S.C., et al., Synthesis and micellar characterization of amphiphilic diblock copolymers based on poly(2-ethyl-2-oxazoline) and aliphatic polyesters. Macromolecules, 1999. 32(6): p. 1847-1852.

54. Korchia, L., et al., Light-switchable nanoparticles based on amphiphilic diblock, triblock and heterograft polyoxazoline. Rsc Advances, 2017. 7(68): p. 42690-42698. 
55. Kampmann, A.L., et al., Synthesis of well-defined core-shell nanoparticles based on bifunctional poly(2-oxazoline) macromonomer surfactants and a microemulsion polymerization process. Rsc Advances, 2016. 6(102): p. 99752-99763.

56. Kampmann, A.L., et al., Formation of Well-Defined Polymer Particles in the Sub-100 nm Size Range by Using Amphiphilic Block Copolymer Surfactants and a Microemulsion Approach. Macromolecular Chemistry and Physics, 2016. 217(15): p. 1704-1711.

57. Eastoe, J., et al., Adsorption of ionic surfactants at the air-solution interface. Langmuir, 2000. 16(10): p. 4511-4518.

58. Lu, J.R., et al., Direct determination by neutron reflection of the structure of triethylene glycol monododecyl ether layers at the air-water-interface. Langmuir, 1993. 9(5): p. 1352-1360.

59. Hines, J.D., et al., Structure of an adsorbed layer of n-Dodecyl-N,N-dimethylamino acetate at the air/solution interface as determined by neutron reflection. Journal of Physical Chemistry B, 1997. 101(36): p. 7121-7126.

60. Brown, W., Light Scattering: Principles and Development 1996: Clarendon Press.

61. Nuyken, O., et al., Systematic investigations on the reactivity of oxazolinium salts. Macromolecular Chemistry and Physics, 1996. 197(1): p. 83-95.

62. Aoi, K. and M. Okada, Polymerization of oxazolines. Progress in Polymer Science, 1996. 21(1): p. 151-208.

63. Guillerm, B., et al., Novel Investigations on Kinetics and Polymerization Mechanism of Oxazolines Initiated by Iodine. Macromolecules, 2010. 43(14): p. 5964-5970.

64. Hoogenboom, R., M.W.M. Fijten, and U.S. Schubert, Parallel kinetic investigation of 2-oxazoline polymerizations with different initiators as basis for designed copolymer synthesis. Journal of Polymer Science Part a-Polymer Chemistry, 2004. 42(8): p. 1830-1840.

65. Hoogenboom, R., M.W.M. Fijten, and U.S. Schubert, The effect of temperature on the living cationic polymerization of 2-phenyl-2-oxazoline explored utilizing an automated synthesizer. Macromolecular Rapid Communications, 2004. 25(1): p. 339-343.

66. Huber, T., et al., New hyperbranched poly(ether amide)s via nucleophilic ring opening of 2-oxazoline-containing monomers. Macromolecular Chemistry and Physics, 1999. 200(1): p. 126-133.

67. Kaya, A., et al., Synthesis of oxazoline functionalized polypropene using metallocene catalysts. Macromolecular Rapid Communications, 2000. 21(17): p. 1267-1271.

68. Kim, K.M., D.K. Keum, and Y. Chujo, Organic-inorganic polymer hybrids using polyoxazoline initiated by functionalized silsesquioxane. Macromolecules, 2003. 36(3): p. 867-875.

69. McAlvin, J.E. and C.L. Fraser, Polymerization of 2-ethyl-2-oxazoline using di-, tetra-, and hexafunctional ruthenium tris(bipyridine) metalloinitiators. Macromolecules, 1999. 32(21): p. 6925-6932.

70. McAlvin, J.E., S.B. Scott, and C.L. Fraser, Synthesis of thermochromic iron(II) tris(bipyridine)-centered star-shaped polyoxazolines and their bipyridine-centered macroligand counterparts. Macromolecules, 2000. 33(19): p. 6953-6964.

71. Paulus, R.M., et al., Acetyl halide initiator screening for the cationic ring-opening polymerization of 2-ethyl-2-oxazoline. Macromolecular Chemistry and Physics, 2008. 209(8): p. 794-800.

72. philippe, D., C. olivier, and R.J. Marie, Handbook of Ring-Opening Polymerization 2009: ILEY-VCH Verlag GmbH \& Co. 429.

73. Uyama, H. and S. Kobayashi, Synthesis of poly(2-oxazoline) macromonomers having a vinyl ester group. Macromolecules, 1991. 24(2): p. 614-615. 
74. Hoogenboom, R., M.W.M. Fijten, and U.S. Schubert, Parallel kinetic investigation of 2-oxazoline polymerizations with different initiators as basis for designed copolymer synthesis. Journal of Polymer Science Part A: Polymer Chemistry, 2004. 42(8): p. 1830-1840.

75. Paulus, R.M., et al., Acetyl Halide Initiator Screening for the Cationic Ring-Opening Polymerization of 2-Ethyl-2-Oxazoline. Macromolecular Chemistry and Physics, 2008. 209(8): p. 794-800.

76. Volet, G., L. Auvray, and C. Amiel, Monoalkyl Poly(2-methyl-2-oxazoline) Micelles. A Small-Angle Neutron Scattering Study. Journal of Physical Chemistry B, 2009. 113(41): p. 13536-13544.

77. Korchia, L., et al., Photodimerization as an alternative to photocrosslinking of nanoparticles: proof of concept with amphiphilic linear polyoxazoline bearing coumarin unit. Polymer Chemistry, 2015. 6(33): p. 6029-6039.

78. Hoogenboom, R., et al., Microwave-assisted synthesis and properties of a series of poly(2-alkyl-2-oxazoline)s. Designed Monomers and Polymers, 2005. 8(6): p. 659671. 